\title{
SELF-EFFICACY ANALYSIS OF SIXTH GRADE MATHEMATICS LEARNING OUTCOMES IN SD N 7 KEBUMEN
}

\author{
Febriana Setyowati, Susilaily Rahmawati, Kartika Chrysti Suryandari \\ Universitas Sebelas Maret \\ febrianasetyowati9@gmai.com
}

\section{Article History}

accepted 30/09/2018

approved 12/10/2018

published 30/10/2018

Keywords

self efficacy, learning

outcomes, mathematics

\begin{abstract}
The essence of mathematics is aimed at solving everyday problems. However, so far mathematics still a subject that is considered difficult. One factor that influences learning success is self-efficacy. This study aims to analyze the level of self-efficacy of sixth grade students on the results of mathematics learning. The sample in this study were all sixth grade students of $S D$ Negeri 7 Kebumen as many as 20 students. This research is a qualitative descriptive study. Data collection techniques use: (1) Questionnaire; and (2) interviews (3) observations and (4) documentation. The analysis used is descriptive qualitative. The results showed that: Students in sixth grade SDN 7 Kebumen had varying levels of self-efficacy. Students who have a high level of self-efficacy get high mathematics learning outcomes, because they have confidence or self-efficacy and are more persistent in facing difficulties. Students who have low levels of efficacy get less satisfying learning outcomes.
\end{abstract}

Social, Humanities, and Education Studies (SHEs): Conference Series https://jurnal.uns.ac.id/shes

p-ISSN 2620-9284

e-ISSN 2620-9292 


\title{
PENDAHULUAN
}

Pendidikan merupakan suatu tindakan atau pengalaman yang mempunyai pengaruh terhadap pertumbuhan dan perkembangan individu. Pendidikan juga merupakan suatu proses yang berkesinambungan dan dilakukan secara bertahap. Menurut UU Sisdiknas Tahun 2003 pendidikan adalah :

\begin{abstract}
"Suatu usaha sadar dan terencana untuk mewujudkan suasana belajar dan proses pembelajaran agar peserta didik secara aktif mengembangkan potensi dirinya untuk memiliki kekutan spiritual keagamaan, pengendalian diri, kepribadian, kecerdasan, akhlak mulia, serta keterampilan yang diperlukan dirinya, masyarakat , bangsa dan negara."
\end{abstract}

Proses belajar mengajar merupakan proses yang paling penting dalam pencapaian tujuan pendidikan. Salah satu usaha untuk menciptakan pendidikan yang berkualitas, tidak hanya mengandalkan pemerintah saja, namun dibutuhkan dukungan dari berbagai pihak seperti guru dan peserta didik itu sendiri. Seorang peserta didik juga harus mampu memposisikan dirinya pada saat proses belajar mengajar. Dalam prosesnya, seseorang memerlukan kedisiplinan, motivasi, kepercayaan diri, minat, bakat, kreativitas, efikasi diri, dan faktor-faktor lain yang dapat mendukung proses belajar. Dari salah satu faktor tersebut hal yang sangat berpengaruh dalam pencapaian hasil belajar yang baik adalah efikasi diri. Tidak jauh berbeda dari factor pendukung lainnya, efikasi diri adalah suatu hal yang terdapat dalam diri manusia yang mempengaruhi individu dalam menentukan tindakan yang akan dilakukan untuk mencapai tujuan. (Ghufron, 2012: 73)

Efikasi diri sebagai evaluasi mengenai kemampuan atau kompetensi seseorang untuk melakukan suatu tugas, mencapai tujuan, dan mengatasi hambatan atau kesulitan. Kesulitan yang sering dialami oleh peserta didik biasanya terdapat pada mata pelajaran tertentu seperti matematika. Matematika merupakan ilmu yang tidak dapat dipisahkan dalam kehidupan sehari-hari. Salah satunya sebagai alat untuk memecahkan masalah, alat komunikasi, alat untuk berfikir logis dan rasional. Namun pada kenyataannya, matematika masih dianggap sulit oleh sebagian besar siswa. Banyak hal yang menjadi faktor kesulitan peserta didik menurut Wigfield dan Meece (Ghufron, 2013: 1) yaitu ; (a) orang orang yang khawatir dengan matematika percaya bahwa mereka tidak punya kemampuan untuk menyelesaikan soal matematika, dan (b) mereka memiliki reaksi emosi yang negative terhadap soal matematika, mereka takut dan tidak menyukai matematika secara terus menerus. Jbeili (Ghufron, 2013: 1) menyatakan bahwa ketidaksukaan siswa terhadap mata pelajaran matematika menurunkan pemahaman siswa terhadap matematika yang mengakibatkan terjadinya ketidakmampuan dalam menyelesaikan tugas sehari-hari lainnya.

Menurut Widayanto (2013:10) Efikasi diri dalam pembelajaran matematika berarti pengendalian situasi seseorang siswa dalam penyelesaian masalah matematis yang diberikan kepadanya sehingga ia berhasil menemukan solusi secara mandiri. Efikasi diri merupakan keyakinan dan harapan mengenai kemampuan individu untuk menghadapi tugasnya. Individu yang memiliki efikasi diri yang rendah merasa tidak memiliki keyakinan bahwa mereka dapat menyelesaikan tugas, maka dia berusaha untuk menghindari tugas tersebut. Keyakinan dalam mengerjakan tugas matematika diperlukan efikasi diri yang tinggi untuk mencapai prestasi belajar yang diharapkan. Dorongan ini berpengaruh dengan pekerjaan yang mengarahkan seseorang untuk mencapai prestasi sebagai suatu usaha untuk mencapai sukses, yang berhasil dalam berkompetensi dengan suatu ukuran 
keunggulan, ini dapat mengacu pada prestasiorang lain atau prestasinya sendiri yang diraih sebelumnya.

Pada observasi yang telah dilakukan di Kelas VI SD N 7 Kebumen, peneliti menemukan bahwa prestasi belajar matematika siswa perlu ditingkatkan karena ada sebagian besar siswa yang nilainya masih di bawah KKM. Siswa dalam pembelajaran matematika masih banyak yang tidak memperhatikan saat guru menjelaskan bahkan masih banyak siswa yang tidak mengerjakan tugas tanpa bantuan dari teman hal ini menunjukan bahwa kurangnya keyakinan yang dimiliki siswa. Prestasi belajar matematika siswa kelas VI SD N 7 Kebumen masih cukup rendah. Siswa belum memiliki keyakinan dengan apa yang mereka pelajari saat ini adalah untuk dirinya di masa depan, dengan hal ini siswa merasa malas, dan beberapa siswa mengalami kesulitan dalam belajar matematika. siswa beranggapan bahwa matematika adalah pelajaran yang sulit dan memerlukan suatu pemikiran yang keras dan otak yang cerdas. Anggapan ini yang menyebabkan mereka tidak meyakini dengan kemampuan mereka dalam belajar matematika.

Berdasarkan kondisi yang telah dipaparkan, efikasi diri akan mempengaruhi hasil belajar matematika. Namun belum diketahui secara jelas tingkat efikasi diri siswa serta pengaruh yang ditimbulkan terhadap hasil belajar matematika siswa. Oleh sebab itu, penelitian ini bertujuan untuk menganalisis tingkat efikasi diri siswa terhadap hasil belajarmatematika kelas VI SDN 7 Kebumen.

\section{METODE}

Jenis penelitian yang dilaksanakan ini adalah penelitian kualitatif. Penelitian ini dilakukan di SD Negeri 7 Kebumen, Kecamatan kebumen, Kabupaten Kebumen. Penelitian ini dilakukan pada tanggal 27-29 September 2018. Sampel dalam penelitian ini adalah seluruh siswa kelas VI SD Negeri 7 Kebumen sebanyak 20 siswa dengan jumlah siswa laki-laki sebanyak 11 anak dan siswa perempuan sebanyak 9 anak. Teknik analisis data yang digunakan adalah triangulasi data dengan teknik pengumpulan data menggunakan: (1) Angket; (2) wawancara; (3) observasi, dan (4) dokumentasi. Pada efikasi diri terdapat 3 aspek yang diukur yaitu : (1) level (tingkat); (2) generality (keadaan umum) dan (3) strength (kekuatan) yang dijabarkan menjadi 7 indikator dengan 37 sub indikator. Analisis yang digunakan adalah deskriptif kualitatif.Dalam penelitian ini angket dihitung menggunakan skala likert, yaitu bentuk skala yang memuat suatu nilai dengan beberapa alternatif jawaban yang dapat dipilih.

\section{HASIL DAN PEMBAHASAN}

Penelitianinidilakukanuntukmengetahuibagaimanatingkat efikasi diri siswa terhadap hasil belajar matematika. Data dalam penelitian ini diperoleh dari angket, wawancara siswa dan guru serta observasi kegiatan pembelajaran matematika. Dari beberapa teknik pengumpulan data tersebut diketahui bahwa tingkat efikasi diri siswa kelas 6 SD N 7 Kebumen bervariasi. Menurut Bandura,1997 (dalam Kartika:2017) terdapat beberapa aspek dalam efikasi diri yang meliputi (1) level (tingkat) yang berkaitan dengan derajat kesulitan tugas; (2) generality (keadaan umum) yang berkaitan dengan luas bidang tingkah laku mana ketika individu merasa yakin terhadap kemampuannya dan (3) strength (kekuatan) yang berkaitan dengan tingkat kekuatan dari keyakinan terhadap kemampuan individu. Ketiga aspek tersebut dijabarkan kembali kedalam beberapa indikator dan diperoleh data sebagai berikut : 
SHEs: Conference Series 1 (2) (2018) 181-186

Tabel 1. Presentase efikasi diri pada siswa kelas VI SD N 7 Kebumen

\begin{tabular}{clc}
\hline Aspek & \multicolumn{1}{c}{ Indikator } & Presentase \\
\hline \multirow{2}{*}{ Level } & Keyakinan siswa terhadap & kemampuannya \\
& sendiri & $74,8 \%$ \\
& Tingkat kesulitan tugas & $68,8 \%$ \\
Generality & Cara mengatasi tantangan tugas & $73,39 \%$ \\
\multirow{2}{*}{ Strength } & Penguasaan materi pembelajaran & $69,38 \%$ \\
& Gigih dalam berusaha & $80,8 \%$ \\
& Ketekunan dalam belajar & $76,6 \%$ \\
& Komitmen dalam belajar & $76,7 \%$ \\
\hline
\end{tabular}

Dari tabel 1 diketahui bahwa keyakinan diri siswa terhadap kemampuannya memecahkan soal matematika sebesar $74,8 \%$, hal ini menunjukkan bahwa sebagian besar siswa yakin akan kemampuan dirinya. Pada tingkat kesukaran soal sebanyak $68,8 \%$ percaya bahwa siswa mampu mengadapi soal matematika. Sebanyak $73,39 \%$ siswa mampu mengatasi tantangan tugas yang diberikan oleh guru. Sedangkan sekitar $69,38 \%$ siswa merasa telah menguasai materi matematika. 80,8\% siswa yakin terhadap hasil ulangan matematika apabila mereka belajar. Sementara itu ketekunan dalam belajar sebesar $76,6 \%$. Komitmen siswa dalam belajar terukur sebesar $76,7 \%$. Hal ini menunjukkan bahwa sebagian besar siswa percaya terhadap dirinya sendiri bahwa mereka akan memiliki hasil belajar yang baik.

Berdasarkan wawancara dengan 10 siswa didapatkan hasil bahwa keyakinan siswa terhadap kemampuannya dalam mengerjakan soal matematika berkisar antara $25 \%$ hingga $80 \%$, beban tugas untuk mata pelajaran matematika dianggap tidak terlalu banyak. Materi yang dipelajari pada mata pelajaran matematika relatif banyak. Seluruh siswa yang diwawancara pernah merasa cemas terhadap nilai matematikanya. Sebagian siswa yakin bahwa dirinya mampu menghadapi kesulitan dan sebagian lain merasa ragu untuk menghadapi kesulitan yang sama. Sebagian siswa memperoleh materi hanya dari guru di sekolah saja dan sebagian lainnya mengikuti les untuk meningkatkan hasil belajar matematika. Sebagian besar siswa tidak mereview kembali materi yang telah dipelajarinya disekolah.

Bandura (1994) menyatakan bahwa hasil yang diharapkan orang sangat tergantung pada efikasi diri masing-masing. "the outcomes people expect are largery dependent on their judgements of what they can accomplish. As a consequence, outcome expectations should not make an independent contribution to predictions of behavior when self-efficacy perceptions are controlled." Hal ini menunjukkan bahwa efikasi diri mempengaruhi hasil belajar, bukan berarti hasil penilaian selalu konsisten namun pada dasarnya siswa menyadari bahwa keterampilan yang mereka miliki sangat berpengaruh pada hasil belajar mereka.

Dari wawancara dengan guru diketahui bahwa siswa yang memiliki nilai yang baik, dalam pembelajaran antusias dan sering bertanya dan mudah dalam menerima materi sehingga memiliki dampak yang positif terhadap hasil belajarnya sedangkan siswa yang memiliki nilai kurang dari KKM selama pembelajaran pasif dan tidak banyak bertanya bahkan tidak bertanya sama sekali, secara pemahaman pun masih dikatakan rendah. Kurangnya keaktifan siswa disebabkan karena siswa belum paham terhadap materi yang disampaikan oleh guru terlebih pada materi yang dianggap cukup sulit seperti perkalian dan pembagian. Terdapat beberapa siswa yang masih malu bahkan enggan bertanya pada teman sebaya untuk menjelaskan kembali materi yang dianggap sulit baginya, meski guru telah mengatur tempat duduk sedemikian rupa dengan siswa yang memiliki hasil belajar yang baik. Siswa juga mudah menyerah ketika menghadapi soal yang sulit namun masih ada siswa yang mau dituntun ketika menghadapi soal yang sulit. Guru juga memberikan kelas tambahan seusai pembelajaran kepada siswa yang memiliki hasil belajar di bawah KKM. Sebagian siswa 
memiliki kesadaran untuk mengikuti les di luar jam sekolah untuk meningkatkan hasil belajar matematikanya.

Sedangkan dari observasi terhadap pembelajaran matematika pada kelas VI SDN 7 Kebumen, didapatkan hasil bahwa terdapat siswa memperhatikan penjelasan guru serta sangat antusias dalam mengikuti pembelajaran, namun beberapa siswa lain tidak memperhatikan.Tidak ada siswa yang bertanya mengenai materi pelajaran. Siswa yang maju ke depan untuk menjawab pertanyaan guru atas dasar keinginannya sendiri. Ada siswa yang berhasil menjawab soal dengan benar, ada pula yang menjawab dengan salah.Siswa yang belum pandai berhitung cenderung mengalami mengalami kesulitan selama pembelajaran matematika. Siswa bersungguh-sungguh dalam mengerjakan soal. Siswa tampak tenang dan serius dalam mengerjakan. Siswa yang kurang pandai berhitung jika menemui soal yang sulit maka dia akan cepat menyerah, sedangkan siswa yang pandai berhitung pantang menyerah dalam menghadapi soal sulit.

Tabel 2. Daftar nilai UTS matematika kelas VI SD N 7 Kebumen

\begin{tabular}{ccc}
\hline No. & Subyek & Nilai \\
\hline 1. & X1 & 60 \\
2. & X2 & 20 \\
3. & X3 & 100 \\
4. & X4 & 90 \\
5. & X5 & 70 \\
6. & X6 & 63 \\
7. & X7 & 85 \\
8. & X8 & 50 \\
9. & X9 & 65 \\
10. & X10 & 100 \\
11. & X11 & 100 \\
12. & X12 & 85 \\
13. & X13 & 88 \\
14. & X14 & 60 \\
15. & X15 & 95 \\
16. & X16 & 55 \\
17. & X17 & 65 \\
18. & X18 & 70 \\
19. & X19 & 100 \\
20. & X 20 & 35 \\
& & Rata-rata \\
\hline
\end{tabular}

Berdasarkan tabel 2 diketahui bahwa rata-rata hasil UTS matematika adalah 72,8. Ketika dibandingkan dengan hasil angket ternyata siswa dengan hasil belajar di atas 80 memiliki efikasi diri yang tinggi sedangkan siswa yang memiliki hasil belajar dibawah 60 memiliki efikasi diri yang rendah. Hal ini sesuai dengan pendapat Andriana dan Leonard (2017) yang menyatakan bahwa efikasi diri memiliki peranan penting dalam memecahkan masalah karena keyakinan siswa terhadap pelajaran matematika akan berpengaruh pada pencapaian prestasi belajarnya.

Bandura, 1997 (dalam Rustika:2012) juga mengemukakan bahwa efikasi diri mempunyai peran yang sangat besar terhadap prestasi matematika dan kemampuan menulis yang diperkuat oleh penelitian Chermes et al. (2001) yang pada penelitiannya menemukan bahwa efikasi diri akademik secara langsung mempengaruhi prestasi akademis dan secara tidak langsung mempengaruhi melalui harapan dan persepsi.

Pervin dan John (dalam Kurniyawati:2012) menyatakan bahwa seseorang yang mempunyai efikasi diri yang tinggi akan lebih termotivasi untuk mencapai tujuan, hal ini 
dicerminkan pada besarnya usaha yang dilakukan serta ketekunan dalam mengatasi rintangan yang ada. la akan terus mengerjakan tugas-tugas yang berkaitan dan tidak mudah menyerah apabila menemui kesulitan. Hal ini sesuai dengan hasil wawancara serta observasi yang telah dilakukan dimana siswa yang memiliki ketekunan, serta tidak mudah menyerah dalam menyelesaikan tugas matematika mendapatkan nilai yang tinggi.

\section{SIMPULAN}

Berdasarkan hasil penelitian dapat disimpulkan bahwa efikasi diri mempengaruhi hasil belajar matematika siswa dengan tingkat efikasi diri siswa pada indikator Keyakinan siswa terhadap kemampuannya sendiri (level) sebesar 74,8\%, Cara mengatasi tantangan tugas (generality) mendapatkan persentase sebesar $73,39 \%$ dan pada indikator gigih dalam berusaha (strength) diperoleh persentase sebesar $80,8 \%$. Siswa yang memiliki efikasi diri yang tinggi mendapatkan hasil belajar yang tinggi, begitu pula sebaliknya pada siswa yang memiliki efikasi diri yang rendah juga mendapatkan hasil belajar yang rendah.

\section{DAFTAR PUSTAKA}

Andriana. I. dan Leonard. (2017). Pengaruh Efikasi diri dan Kemandirian Belajar Terhadap Pemecahan Masalah Matematika (Versi Elektronik). Prosiding Diskusi Panel Nasional Pendidikan Matematika. Diperoleh tanggal 11 september 2018 dari http://journal.Ippmunindra.ac.id/index.php/repository/article/view/1958

Bandura. A. (1994). Self-Efficacy. (Versi Elektronik). Diperoleh pada tanggal 4 juli 2018 dari http://www.des.emory.edu/mfp/BanEncy.html

Ghufron. M. N., Suminta R.R. (2012). Teori-teori Psikologi. Yogyakarta. Ar-Ruzz Media

Ghufron, M. N., \&Suminta, R. R. (2013). EfikasiDiridanHasilBelajarMatematika: Metaanalisis (Versi Elektronik). BuletinPsikologi, Volume 21(1), 20. Diperoleh $\begin{array}{lllll}\text { tanggal tanggal } & 04 & \text { juli } & 2018 & \text { dari }\end{array}$ https://journal.ugm.ac.id/buletinpsikologi/article/view/9843

Kartika. M. Y. (2017). Hubungan Antara Efikasi Diri Matematika Dengan Kemandirian Belajar Matematika Pada Siswa Kelas VIII Di SMP Negeri 1 Padasuka Lampung (versi elektronik). Diperoleh tanggal Diperolehtanggal 29 September $2018 \quad$ dihttp://repository.uksw.edu/bitstream/ 123456789/13187/1/T1_802013120_Full\%20text.pdf

Kurniyawati. R. (2012). Hubungan Antara Efikasi Diri Dengan Motivasi Belajar. Naskah Publikasi. Diperoleh pada tanggal 10 oktober 2018 dari http://eprints.ums.ac.id/21434/11/NASKAH_PUBLIKASI.pdf

Rustika. M. (2012). Efikasi Diri: Tinjauan Teori Albert Bandura (Versi Elektronik). Buletin Psikologi, Volume 20 (1-2). 18-25 Diperoleh tanggal tanggal 10 Oktober 2018 dari https://jurnal.ugm.ac.id/buletinpsikologi/article

Widiyanto. A. (2013). Pengaruh Self-Efficacy dan Motivasi Berprestasi siswa Terhadap Kemandirian Belajar Mata pelajaran K3(Keselamatan dan Kesehatan kerja) di unduh 16 Januari 2017 pada http://eprints.uny.ac.id/10052/1/JURNAL.pdf 